\title{
Deteksi Radar Terhadap Multi-Object Bergerak Dengan Pemrosesan Doppler
}

\author{
Radar Detection of Multi-Objects Movement With Using Doppler Processing \\ Reyhan Fahmirakhman Abdullah ${ }^{1 *}$, Dharu Arseno², Fiky Yosef Suratman ${ }^{3}$ \\ ${ }^{1,2}$ Program S1 Teknik Telekomunikasi, Fakultas Teknik Elektro, Universitas Telkom \\ ${ }^{3}$ Program S1 Teknik Elektro, Fakultas Teknik Elektro, Universitas Telkom
}

\begin{tabular}{l} 
ARTICLE INFO \\
\hline Article history: \\
DOI: \\
10.30595/pspfs.v1i.128 \\
Submitted: \\
June 28, 2021 \\
Accepted: \\
July 14, 2021 \\
Published: \\
Oct 31, 2021 \\
\hline
\end{tabular}

\begin{abstract}
In general, Radar or Radio Detection and Ranging is an electromagnetic wave system that is useful to measure distance and answer and make maps of surrounding objects. Radar has an advantage compared to other navigation tools, which is that radar does not require a transmitter station as a transmitter. Radar has an electronic wave emission principle that emits short radio wave pulses emitted in a narrow beam by a directional antenna. In this study, a multi-object radar detection simulation was carried out using Dopler processing both MTI and PDP, which later on the radar will detect related objects. Multi-object here is a condition that is achieved when a navigation radar detects more than one object. The result of this research is a multiobject detection process using the MTI and PDP methods and the matched-filter obtained from the predetermined data. So Doppler processing aims to mitigate the clutter signal to improve the detection performance of moving targets even though there is a dominance of signals originating from stationary clutter.
\end{abstract}

This work is licensed under a Creative Commons Attribution 4.0 International License.

Keywords:

Doppler Effects, Moving Target

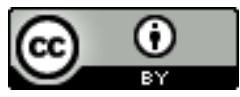

Indication, Pulse Doppler

Processing, Signal Modeling

\author{
Corresponding Author: \\ Reyhan Fahmirakhman Abdullah \\ Program S1 Teknik Telekomunikasi, Fakultas Teknik Elektro, Universitas Telkom \\ J1. Telekomunikasi, Bandung, Jawa Barat 40257 \\ Email: reyhanfahmirakhman@gmail.com
}

\section{PENDAHULUAN}

Secara umum Radar atau Radio Detection and Ranging merupakan suatu system gelombang elektromagnetik yang berguna untuk mengukur jarak Radar memiliki prinsip pancaran gelombang yang mana memancarkan pulsa gelombang radio pendek yang dipancarkan dalam alur semput (narrow beam) oleh antenna berarah (directional antenna) Monitoring lalu lintas udara merupakan salah satu bentuk penerapan radar yang dapat kita jumpai disekitar kita, Monitoring lalu lintas udara merupakan media pelayanan pemanduan lalu lintas udara terhadap pesawat terbang. Pada dasarnya radar mempunyai banyak aplikasi yang spesifik, tetapi secara umum radar mempunyai tiga fungsi atau mode, yaitu: untuk mencari (search) atau pengintai (surveillence), melacak (track) dan membuat citra (image) (Mark A Richard, 2014).

Pada umumnya deteksi target dapat dibedakan menjadi dua keadaan, yang pertama adalah null hypothesis, merupakan suatu keadaan tidak ada sinyal echo (tidak ada target), dan alternative hypothesis testing, dimana terdapat sinyal echo (terdapat target). Pemrosesan Doppler merupakan istilah yang digunakan untuk penapisan (filtering) atau analisa spektral dari sinyal echo dari jarak tertentu dan periode tertentu yang dihasilkan oleh beberapa pulsa yang ditransmisikan sinyal radar (slow times) (Mark A Richard, 2014)(Richards et al., 2010).Doppler dapat dibedakan menjadi dua tipe pemrosesan, yaitu Moving Target Indication (MTI) dan Pulse Doppler Processing (PDP). Keduanya 
menggunakan konsep pergeseran frekuensi Doppler dan efek Doppler untuk mendeteksi target bergerak (Richards et al., 2010).

Pada penelitian ini dilakukan percobaan pendeteksian terhadap multi-object bergerak dengan menggunakan pemrosesan Doppler. Dimana pemrosesan Doppler menggunakan Moving Target Indication (MTI) dan Pulse Doppler Processing (PDP). Multi-object disini merupakan suatu keadaan yang tercapai apabila ada lebih dari satu objek yang terdeteksi, khususnya oleh suatu radar navigasi. Dalam penelitian ini dilakukan juga simulasi pemodelan sinyal echo serta analisa tahapan sampai akhirnya suatu target dapat terdeteksi.

\section{METODE PENELITIAN}

Radar

Radio Detection and Ranging (RADAR) merupakan sistem elektromagnetik yang digunakan untuk deteksi objek dan lokasi dalam jarak tertentu (Skolnik, 1990). Selain mengindentifikasi dari suatu objek tertentu sinyal echo juga dapat mengidentifikasi lama proses dari delay yang telah berlalu antara sinyal echo yang diterima dan energi elektromagnetik yang akan di trasmisikan. Sinyal gelombang elektromagnetik yang ditransmisikan radar kesuatu objek sebagian dari sinyal gelombang elektromagnetik akan diteruskan dan dikembalikan ke target dengan cara dipantulkan. Antena menerima sinyal pantulan gelombang elektromagnetik kemudian diterima oleh receiver.

\section{Threshold detector}

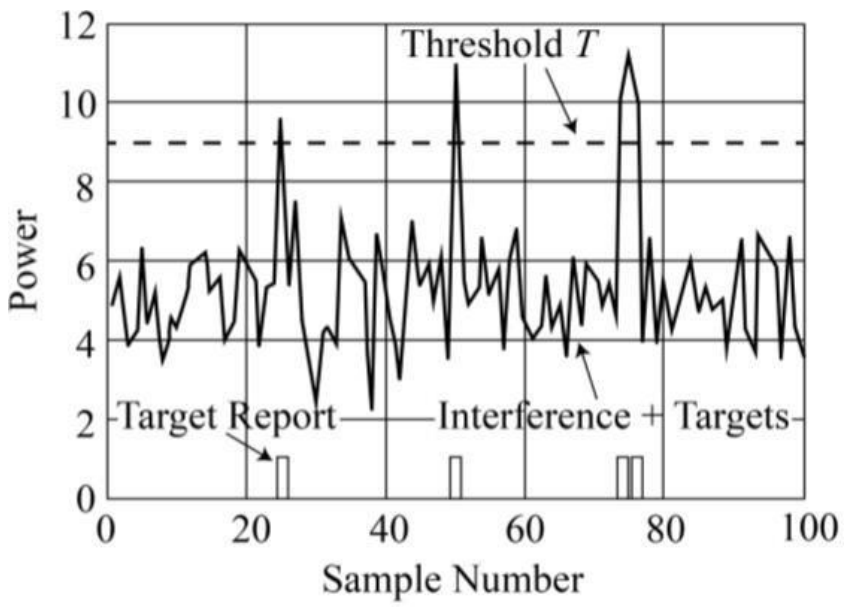

Gambar 1. Konsep dari threshold detection (Mark A. Richards, 2015)

Data radar yang ditampilkan gambar (1) merupakan clutter dan sinyal target yang mewakili variasi dalam kekuatan sinyal yang diterima dibanding dengan jangkauan untuk satu pulsa yang ditransmisikan. Ditampilkan pada data radar bahwasannya terdapat target yang melewati ambang, itu menunjukkan adanya target pada rentang yang berbeda.

\section{Pulse-doppler radar}

Pulse-Doppler Radar merupakan sistem radar yang menentukan jangkauan target dan menggunakan teori efek doppler dari sinyal yang dikembalikan untuk menentukan kecepatan objek target. Apabila target mendekati radar maka frekuensi Doppler akan positif begitupun sebaliknya (Shekhar, 2020). Persamaan frekuensi Doppler diberikan dalam persamaan (2).

$$
f d=\frac{2 V r}{\lambda}=\frac{2 v \cos \theta}{\lambda}
$$

Frekuensi Doppler maksimum yang dapat terdeteksi oleh radar tanpa terjadi aliasing berbanding lurus dengan Pulse Repetition Frequency (PRF).

$$
-\frac{P R F}{2} \leq f d \leq \frac{P R F}{2}
$$

\section{Pulse Repetition Frequency (PRF)}

Pada Pulse Repetition Frequency (PRF) merupakan banyaknya jumlah siklus transmit atau receive yang telah selesai oleh radar per detik, yang mana diukur dengan pulse-per-second (PPS) tetapi sering dinyatakan dalam Hertz. Dan untuk rumus dari PRF dapat dilihat dari persamaan (4). 


$$
P R F=\frac{1}{\mathrm{PRI}}
$$

\section{Fast Fourier transform (FFT)}

Fast fourier transform adalah penerapan dari transformasi fourier diskrit (DFT) yang telah dioptimasi sedangkan DFT adalah FFT pada domain waktu diskrit. Prinsip kerja FFT adalah membagi sinyal hasil penyamplingan menjadi beberapa bagian yang sama dan hasilnya dikumpulkan kembali. FFT juga merupakan algoritma cepat untuk menghitung DFT (Heckbert, 1995). Persamaan (5) merupakan rumus dari DFT (Averaging \& Kosinus, 2020).

$$
X(k)=\sum_{n=0}^{N-1} \mathrm{x}(\mathrm{n}) \cdot W_{N}^{n k}, k=0,1,2 \ldots ., N-1
$$

Sementara itu inverse discrete fourier transform (IDF) mengembalikan sinyal dari domain frekuensi ke domain waktu diskrit yang ditunjukkan pada persamaan (6) (Pradipta, 2011).

$$
X[k]=\frac{1}{N} \sum_{n=0}^{N-1} \mathrm{x}[\mathrm{k}] \cdot e^{\frac{J 2 \pi n k}{N}}, n=0,1,2 \ldots ., N-1
$$

\section{Linear Frequency Modulation (LFM) waveform}

Dalam pembentukan gelombang LFM dibagi menjadi dua bagian, yang pertama adalah teknik analog dan yang kedua adalah teknik digital, yang mana memberikan keuntungan dari fleksibilitas, stabilitas, akurasi dan pengulangan (Patel et al., 2012).Gambar (2) merupakan pengilustrasian bentuk gelombang LFM.

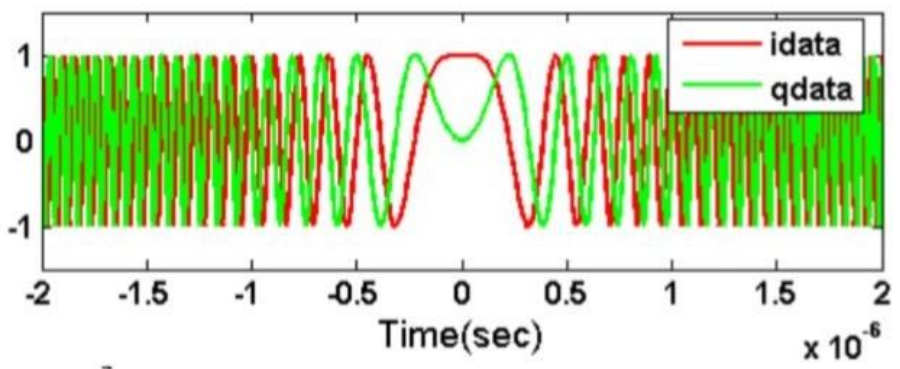

Gambar 2. Ilustrasi bentuk gelombang LFM

\section{Moving Target Indication (MTI)}

Merupakan mode operasi radar untuk memisahkan target bergerak dari gangguan atau clutter, tetapi tidak sampai pada menyediakan informasi kecepatan dari target. Radar MTI mempunyai karakteristik adalah sinyal yang ditransmisikan harus koheren dengan sinyal referensi dari receiver.

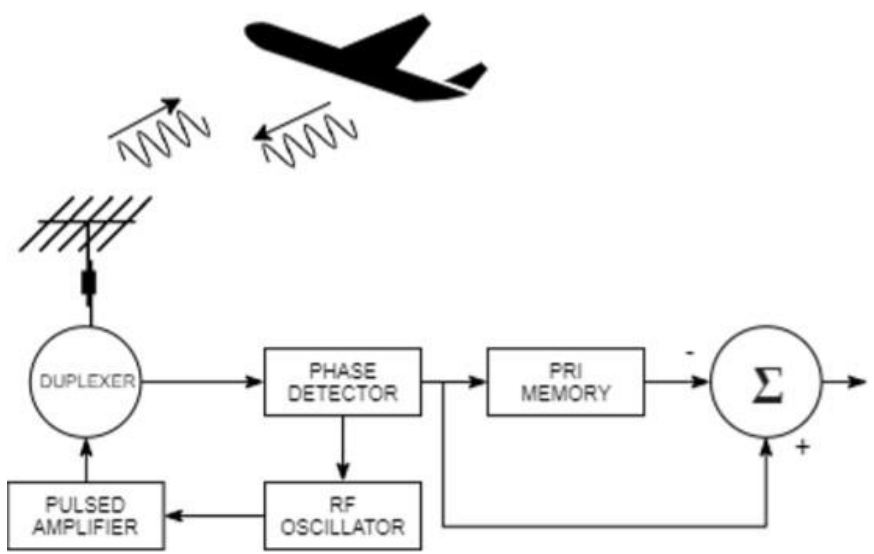

Gambar 3. Blok diagram sederhana dari sistem MTI yang koheren 


\section{Pulse canceller}

Proses MTI dibuat dari pulse canceller diikuti oleh Fourier diskrit (DFT). Dalam Pulse Canceller mengurangi pengembalian dari pulsa berurutan, dengan asumsi stasionary clutter identik dan akan dibatalkan. Konsep ini akan gagal apabila pulse berurutan diberi kode berbeda (Levanon et al., 2017).

\section{Hamming window}

Fungsi windowing atau weighting merupakan fungsi matematika untuk memilih beberapa interval luar yang bernilai nol. Fungsi yang bernilai ini terangkai secara simetris dari pusat peak menuju kedua ujungnya (Arief \& Soleh, 2014).Kita dapat membuat window dengan menyesuaikan ukuran kernel untuk mencapai bentuk pembatalan yang diinginkan (F. J. Harris, 1978).

\section{Matched filter}

Matched filter merupakan proses untuk mendeteksi bagian sinyal yang diketahui dalam suatu noise (Bancroft, 2002). Filter akan memaksimalkan SNR dari sinyal terdeteksi yang berhubungan dengan noise pada titik waktu yang sesuai dengan penundaan ke target.

\section{Efek doppler}

Efek Doppler merupakan pergeseran frekuensi yang dihasilkan dari gerak relatif antara sumber dan penerima gelombang. Akibatnya adanya gerakan relatif antara radar dan target, frekuensi gelombang elektromagnetik yang dipantulkan dari target dan diterima oleh radar berbeda frekuensi gelombang yang di transmisikan dari radar (Mark A Richard, 2014)(C., 2011)

\section{Perancangan sistem}

Pada penelitian ini akan dilakukan perancangan sistem pendeteksian radar dengan tujuan untuk mendeteksi multiobject bergerak dengan menggunakan pemrosesan Doppler.

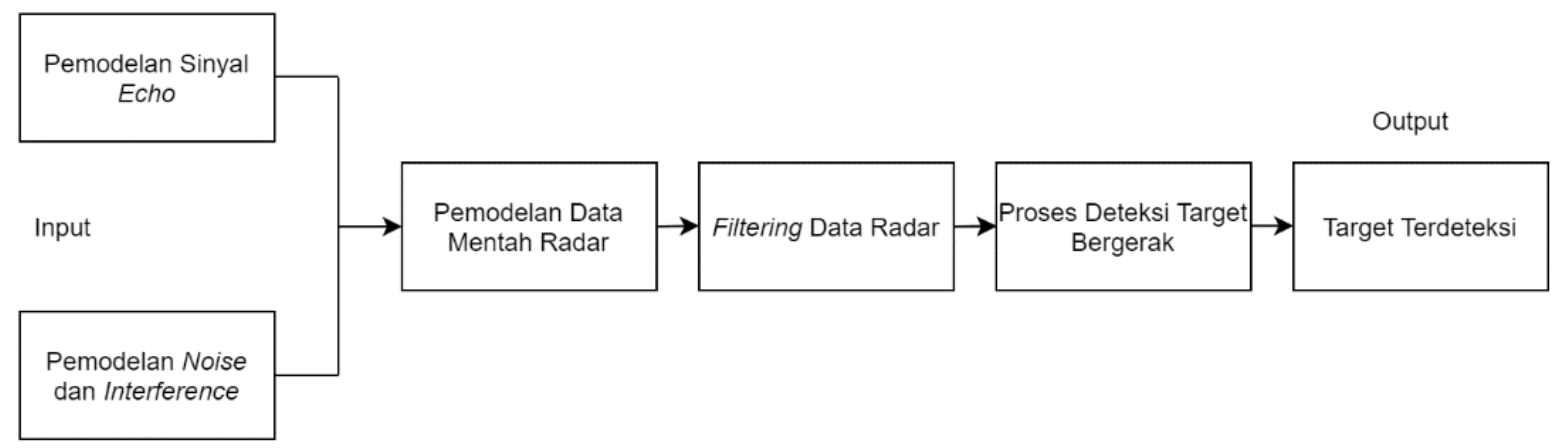

Gambar 4. Diagram Blok Sistem

Gambar (4) merupakan sistem pendeteksian radar pada penelitian ini. Pertama merupakan pemodelan sinyal echo, dimana bentuk gelombang linear frequency modulation (LFM) merupakan hasil dari pemodelan sinyal echo ini. Setelah itu akan dilakukan pemodelan Noise dan Interference, dengan hasil keluaran berupa sinyal clutter. Selanjutnya merupakan pembentukan data mentah radar, dalam tahapan ini sinyal chirp dan sinyal clutter akan diolah menggunakan metode Doppler processing. Pada proses ini data radar diaplikasikan menggunakan three-pulse canceller. Kemudian pada proses filtering ini hasil yang didapatkan belum sesuai yang diharapkan sehingga akan masuk ke proses selanjutnya. Kemudian proses deteksi target bergerak, pada proses ini menggunakan metode matched filter. Akan ditampilkan hasil dari proses berupa simulasi dari target yang berhasil terdeteksi oleh radar, pada simulasi dapat diketahui target yang tidak berhasil terdeteksi oleh sistem radar.

\section{HASIL DAN PEMBAHASAN}

Sistem yang diujikan melakukan simulasi deteksi multi-object bergerak pada radar dengan menggunakan pemrosesan Doppler. Dalam proses pengujian dilakukan beberapa langkah pengerjaan sehingga dapat terbentuk suatu sistem yang dapat mendeteksi target bergerak pada radar, seperti berikut:

\section{Analisa Hasil Masukan Simulasi}

Pada analisis ini menjelaskan tentang masukan yang diperoleh pada simulasi dengan bantuan program software. Masukan pada simulasi ini berupa pemodelan sinyal echo serta pemodelan noise dan interference. 


\section{Inisialisasi Parameter Variabel}

Dalam penelitian kali ini terdapat beberapa parameter yang digunakan untuk mendukung dan menjadi acuan dalam proses perhitungan dan analisis. Parameter yang digunakan tercantum dalam tabel 1.

Tabel 1. Parameter simulasi radar

\begin{tabular}{cccc}
\hline Parameter & Nilai & Satuan & Simbol \\
\hline Panjang Pulsa & $10^{-6}$ & seconds & $\mathrm{T}$ \\
Chirp Bandwidth & $10^{6}$ & $\mathrm{~Hz}$ & $\mathrm{~W}$ \\
Chirp Sampling Rate & $12 \times 10^{6}$ & $\mathrm{~Hz}$ & $f_{s}$ \\
Number of Pulses & 20 & pulses & $\mathrm{Np}$ \\
Pulse Repetition Frequency & $25 \times 10^{6}$ & $\mathrm{~Hz}$ & PRF \\
Start Time of Range Window & $12 \times 10^{-6}$ & seconds & T_out[1] \\
End Time of Range Window & $38 \times 10^{-6}$ & seconds & T_out[2] \\
System Reference & 0 & seconds & T_ref \\
Frekuensi Radar & $10^{9}$ & $\mathrm{~Hz}$ & $f_{c}$ \\
\hline
\end{tabular}

\section{Pemodelan Sinyal Echo}

Tahapan awal dalam penelitian ini adalah pemodelan sinyal echo, yang mana akan diasumsikan sebagai target bergerak pada radar. Disini jumlah pulsa yang dibutuhkan sebanyak 20, JKL dimisalkan sebagai pulse index array, serta diketahui bahwasannya nilai PRF adalah $25 \times 10^{-6} \mathrm{~Hz}$. Dengan demikian rumus dari Pulse Repetition Interval (PRI) adalah PRI=1/PRF, dengan rumus jarak antar interval rua = rmax - rmin. Untuk mendapatkan nilai dari relative start time of pulses, dilakukan perkalian antara PRI dan JKL. Dan untuk mendapatkan data kecepatan Doppler digunakan rumus (7).

$$
V_{d}=\frac{c P R F}{2 f_{c}}
$$

Setelah perhitungan untuk data mentah yang dibutuhkan untuk membuat sinyal chirp didapatkan, lalu disimulasikan pembuatan sinyal chirp dengan menggunakan data mentah dengan bantuan simulasi software. Disini diketahui multiobject bergerak berjumlah 4 target banyaknya, selanjutnya nilai dari jarak, SNR dan kecepatan setiap target akan dijabarkan pada tabel 2.

Tabel 2. Tabel data target bergerak

\begin{tabular}{lllll}
\hline & T1 & T2 & T3 & T4 \\
\hline Jarak & $2 \times 10^{3} \mathrm{Km}$ & $2.7 \times 10^{3} \mathrm{Km}$ & $3.1 \times 10^{3} \mathrm{Km}$ & $3.5 \times 10^{3} \mathrm{Km}$ \\
SNR & $10 \mathrm{~dB}$ & $20 \mathrm{~dB}$ & $15 \mathrm{~dB}$ & $20 \mathrm{~dB}$ \\
Kecepatan & $-11.5 \mathrm{~m} / \mathrm{sec}$ & $-56.25 \mathrm{~m} / \mathrm{sec}$ & $37.5 \mathrm{~m} / \mathrm{sec}$ & $93.75 \mathrm{~m} / \mathrm{sec}$ \\
\hline
\end{tabular}

Kemudian pada gambar (5) merupakan hasil dari pemodelan sinyal echo, ditunjukkan hasil dari pemodelan ini berbentuk gelombang linear frequency modulation (LFM), butuh sebanyak 120 sinyal chirp yang kompleks dalam pembentukan gelombang LFM. Pada gambar (5) juga ditunjukkan dua buah sinyal berwarna merah dan biru. Untuk sinyal berwarna biru diasumsikan bernilai real sedangkan sinyal yang berwarna merah diasumsikan bernilai imajiner. 


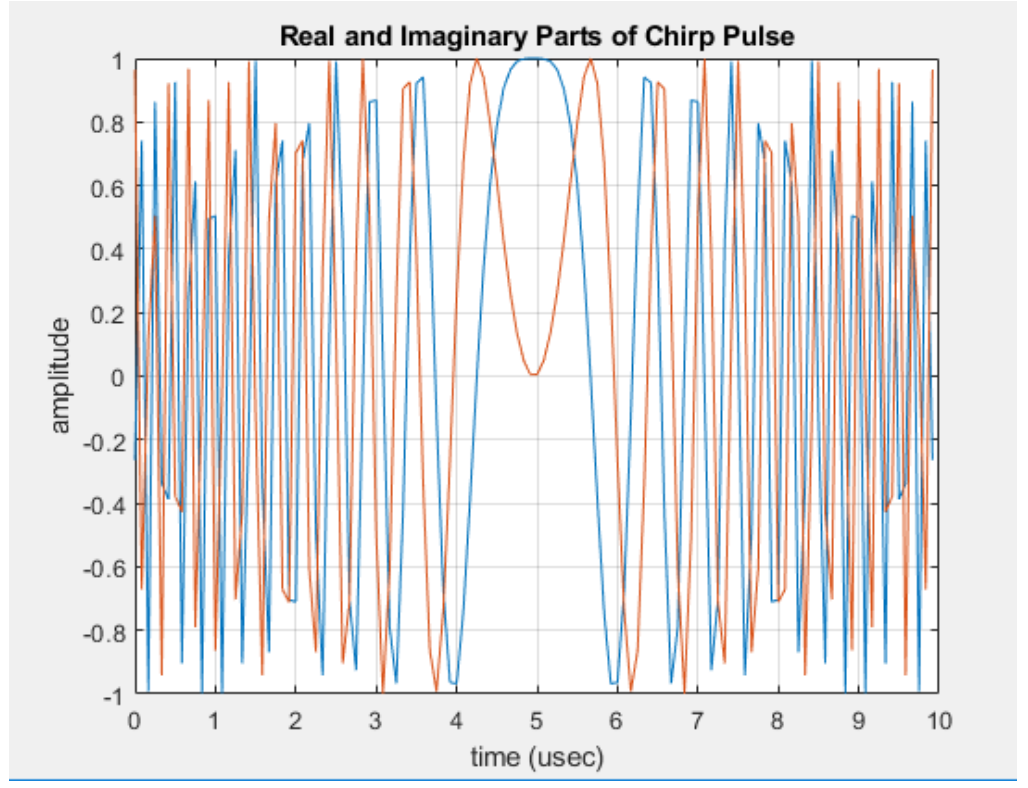

Gambar 5. Hasil pemodelan sinyal echo

\section{Pemodelan Noise dan Interference}

Selanjutnya merupakan proses pemodelan Noise dan Interference, proses ini dimulai dari pembentukan range bin pulse-number map untuk pembentukan sinyal komponen. Pada proses ini pemodelan sinyal noise diasumsikan sebanyak 20 pulsa serta diproses secara berulang. Sinyal clutter merepresentasikan antara jarak dan amplitudo, yang diasumsikan pada software berulang hingga 20 pulsa yang ditumpuk. Hasil dari pemodelan Noise dan Interference ini ditunjukkan pada gambar (6).

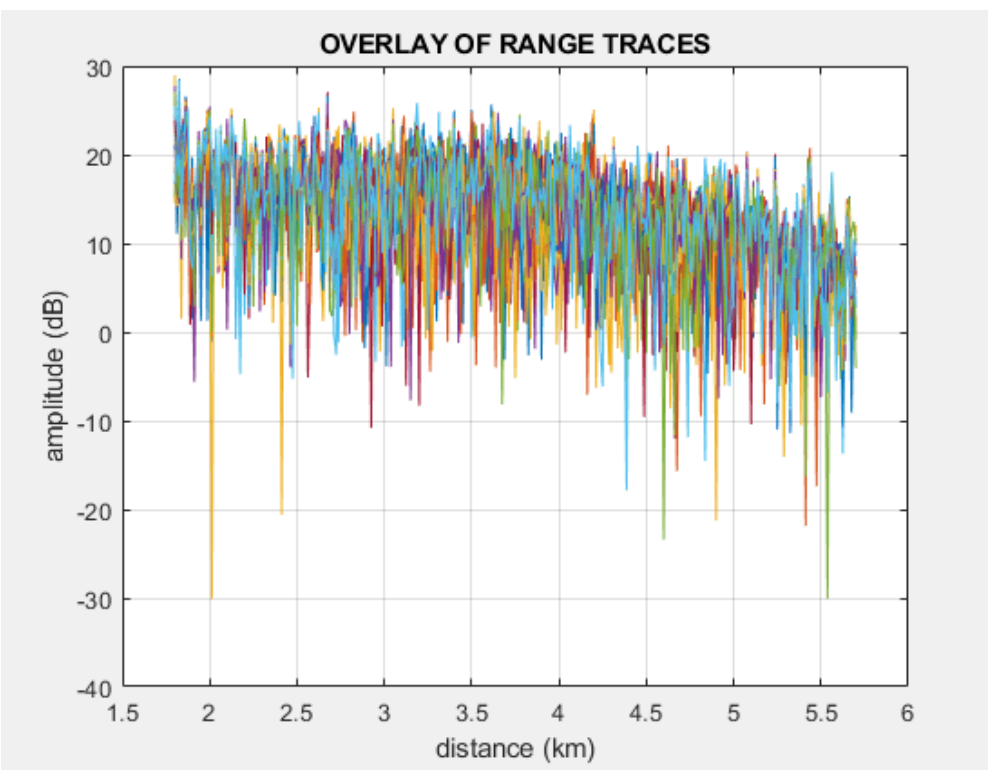

Gambar 6. Hasil dari pemodelan sinyal noise

\section{Analisa Hasil Proses Simulasi}

Setelah mendapatkan hasil masukan berupa pemodelan sinyal echo serta pemodelan noise dan interference, kemudian didapatkan hasil dari proses selanjutnya untuk pendeteksian multi-object bergerak.

\section{Pemodelan data mentah radar}

Pada proses ini sinyal echo dan sinyal clutter akan diproses menggunakan Doppler processing untuk pemrosesan data mentah radar, serta diasumsikan semua objek akan terdeteksi akan tetapi masih adanya interferensi dari ground 
clutter pada sistem radar ini. Pada simulasi ini panjang FFT yang dipakai adalah $L f f t=32$. Dan untuk pembentukan data mentah dengan menggunakan metode Hamming-window. Terlihat pada gambar 7 terdapat clutter yang mengganggu multi-object bergerak pada frekuensi tengah sistem radar, serta terlihat juga target yang terdeteksi oleh sistem radar yang letaknya tepat di kanan dan kiri. Apabila target bergerak dengan kecepatan negatif maka target bergerak menjauhi radar, dan begitu sebaliknya.

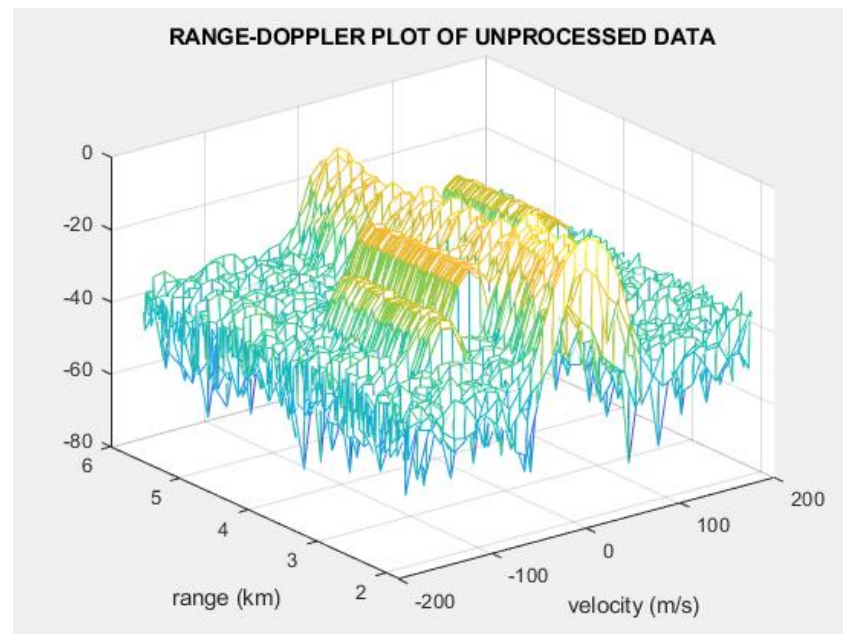

Gambar 7. Hasil colormap-plot pembentukan data mentah radar

Pada gambar (8) merupakan hasil dari contour-map plot, terlihat jelas clutter menginterferensi multi-object pada titik nol sistem radar, akibatnya sistem radar tidak dapat mendeteksi multi-object bergerak.

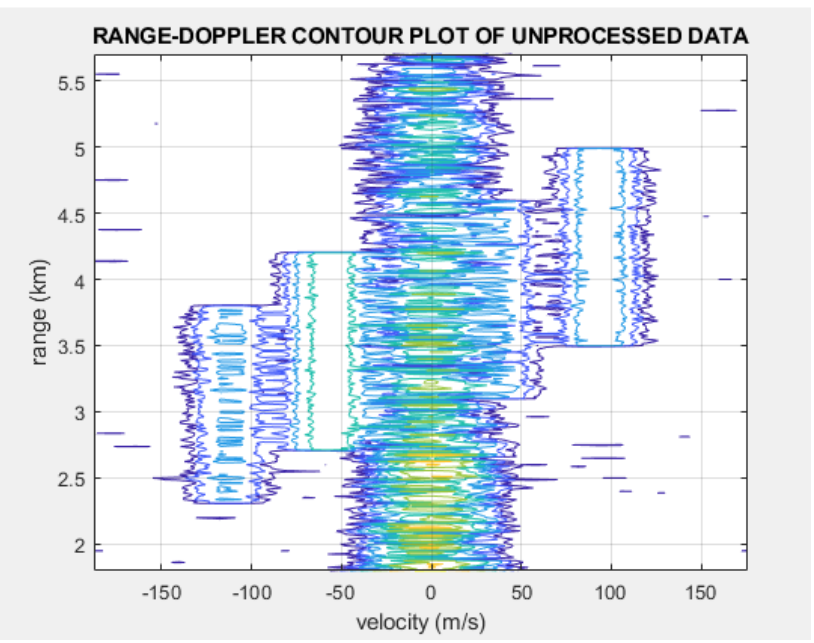

Gambar 8. Hasil contourmap-plot pembentukan data mentah radar

\section{Filtering data radar}

Proses filtering atau penyaringan data ini diasumsikan dengan menggunakan data mentah radar dari proses sebelumnya. Penggunaan three-pulse canceller dimaksudkan untuk mendapatkan hasil yang maksimal. Proses ini akan menyaring clutter yang terdapat pada frekuensi tengah sistem radar, setelah dilakukan penyaringan clutter akan menyebar menjauhi titik nol sehingga menginterferensi target, proses ini dinamakan scattering clutter.Hasil proses tersebut divisualisasikan pada gambar 9 dan 10. 


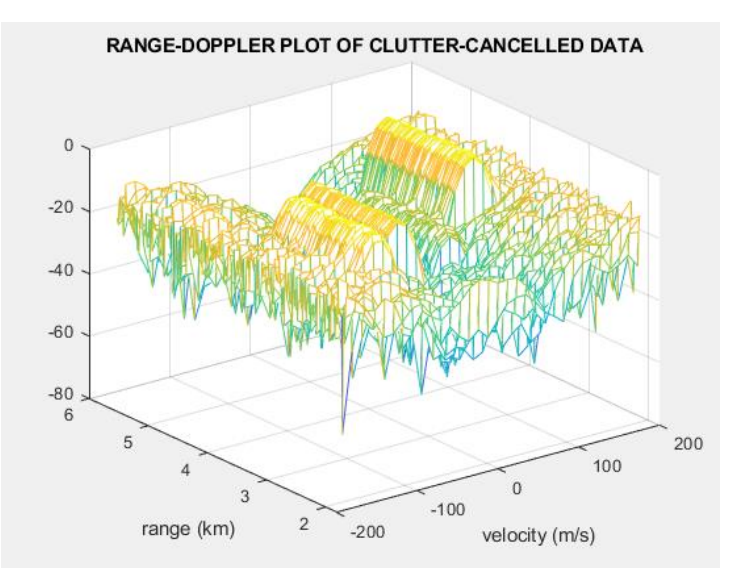

Gambar 9. Hasil proses filtering data radar mesh-colormap plot

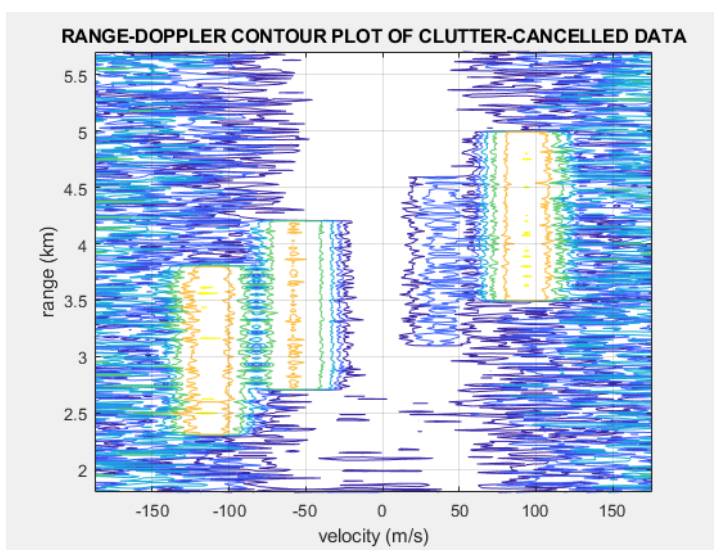

Gambar 10. Hasil proses filtering data radar contourmap-plot

\section{Pengolahan Data Radar}

Proses terakhir untuk mendapatkan hasil yang diharapkan adalah proses pendeteksian target bergerak, proses ini menggunakan matched-filter. Clutter yang semula terhambur dan mengganggu akan hilang dari sekeliling objek bergerak. Akan tetapi proses ini mempengaruhi sinyal dari multi-object bergerak. Pada proses ini akan terlihat objek yang tidak terdeteksi dengan baik karena daya yang terdeteksi sangat kecil. Oleh karena itu sistem radar menganggap objek tersebut merupakan false detection. Hasil proses tersebut divisualisasikan pada gambar 11 dan 12.

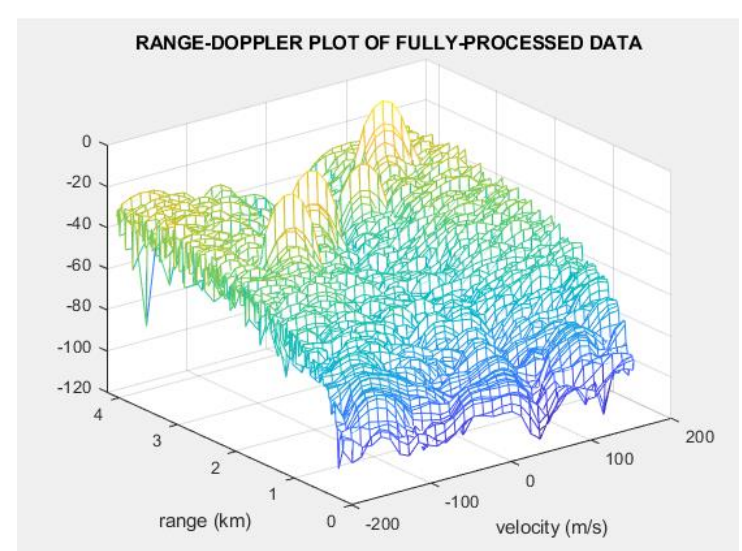

Gambar 11. Hasil simulasi processing data radar mesh-colormap plot 


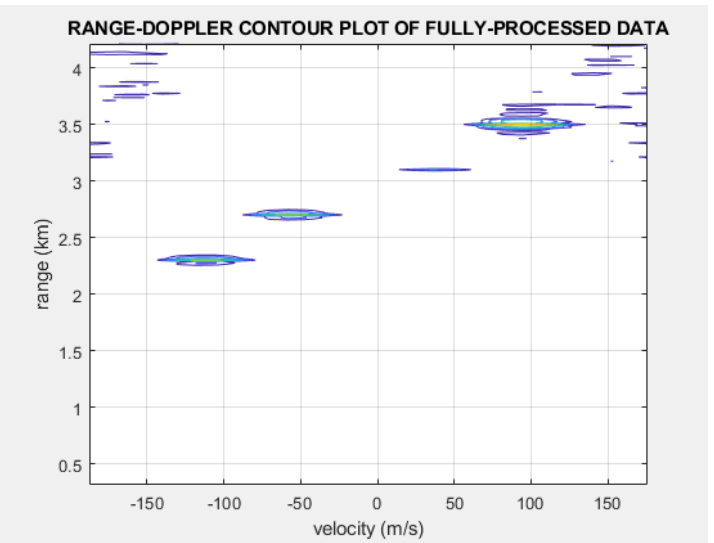

Gambar 12. Hasil simulasi processing data radar contourmap-plot

\section{KESIMPULAN}

Pada simulasi yang telah dilakukan yaitu pendeteksian multi-object bergerak menggunakan pemrosesan Doppler dan berdasarkan pada hasil simulasi serta analisis penelitian yang telah dilakukan, dapat ditarik kesimpulan sebagai berikut:

1. Proses pendeteksian multi-object bergerak dengan menggunakan pemrosesan doppler ini dilakukan dengan menggunakan bantuan program software.

2. Dalam simulasi ini diasumsikan multi-object berjumah 4 target dan juga diperlukan beberapa parameter pendukung serta variabel yang berisi informasi jarak, SNR dan kecepatan setiap target.

3. Pada simulasi ini menggunakan dua masukan yaitu pemodelan sinyal echo serta pemodelan noise dan interference. Dimana keluaran dari proses pemodelan sinyal echo berbentuk gelombang Linear Frequency Modulation (LFM).

4. Untuk mendapatkan target yang dapat terdeteksi dengan baik diperlukan beberapa tahapan dalam simulasi ini antara lain pemodelan data mentah radar, filtering data radar, dan pengolahan data radar.

5. Simulasi ini bertujuan untuk melihat pengaruh setiap metode terhadap hasil akhir metode yang dihasilkan.

\section{UCAPAN TERIMA KASIH}

Ucapan terima kasih disampaikan kepada semua pihak yang telah berperan dalam penelitian ini yang berjudul "Deteksi radar terhadap multiobject bergerak dengan pemrosesan doppler", sehingga penelitian ini dapat dituangkan dalam bentuk tulisan dan diinformasikan kepada pihak yang membutuhkan.

\section{DAFTAR PUSTAKA}

Arief, R., \& Soleh, M. (2014). Analisis Pengaruh Windowing Dalam Pembentukan Citra. Prosiding Seminar Nasional Penginderaan Jauh 2014, 178-187.

Averaging, S., \& Kosinus, D. A. N. J. (2020). Pengenalan Akor Menggunakan SHPS, Chord Recognition Using SHPS, Segment Averaging, and Cosine Distance.

Bancroft, J. C. (2002). Introduction to matched filters. Report, 14(1988), 1-8.

C., V. C. (2011). The Micro-Doppler Effect in Radar.

F. J. Harris. (1978). On the Use of Windows for Harmonic Analusis with the Discrete. Proceedings of the IEEE, 66, 51-83.

Heckbert, P. (1995). Fourier Transforms and the Fast Fourier Transform (FFT) Algorithm. Notes Computer Graphics, $3(2), 15-463$.

Levanon, N., Cohen, I., \& Itkin, P. (2017). Complementary pair radar waveforms-evaluating and mitigating some drawbacks. IEEE Aerospace and Electronic Systems Magazine, 32(3), 40-50.

Mark A. Richards, P. D. (2015). Fundamentals of Radar Signal Processing, Second Edition. In Acta Universitatis Agriculturae et Silviculturae Mendelianae Brunensis (Vol. 53, Issue 9).

Mark A Richard. (2014). Fundamentals of Radar Signal Processing. McGraw-Hill. 
Patel, K., Neelakantan, U., Gangele, S., Vacchani, J. G., \& Desai, N. M. (2012). Linear frequency modulation waveform synthesis. 2012 IEEE Students' Conference on Electrical, Electronics and Computer Science.

Pradipta, N. (2011). Implementasi Algoritma FFT (Fast Fourier Transform) Pada Digital Signal Processor (DSP) TMS320C542. Implementasi Algoritma FFT (Fast Fourier Transform) Pada Digital Signal Processor (DSP) TMS320C542, Universitas Diponegoro, 1-7.

Richards, M. A., Scheer, J. A., \& Holm, W. A. (2010). Principles of modern radar: Basic principles. In Principles of Modern Radar.

Shekhar, C. (2020). Pulse Doppler Processing - A Novel Digital Technique. Iciccs, 1089-1095.

Skolnik, M. i. (1990). Radar Hanbook. In McGraw-Hill (Vol. 53). 